\title{
TINJAUAN HUKUM EKONOMI ISLAM PADA POLA JUAL BELI JAGUNG KUNING (STUDI KASUS DESA MALALA KABUPATEN TOLI-TOLI)
}

\author{
Nasrul $^{1}$, Sapruddin ${ }^{2}$, Fadliah Mubakkirah ${ }^{3}$ \\ ${ }^{1}$ Mahasiswa ${ }^{2,3}$ Dosen Institut Agama Islam Negeri Palu \\ nasrul@gmail.com
}

\begin{abstract}
Malala Village is an area in Dondo sub-district, Tolitoli district, where some of the people earn income from farming. One of them is Corn. The results of the corn farming activity are then traded through collectors. In this corn trading system there is a difference in the bargaining position of each farmer, namely farmers who receive seed capital assistance from collectors get a lower bargaining position, in exchange they get groceries from collectors according to the agreement at the beginning of the agreement, while farmers without seed assistance from collectors get a normal bargaining position. Farmers who get a low bargaining position feel disadvantaged, but they continue to do so because they do not have seed capital. This buying and selling system has become a habit of the local community. According to researchers, the pattern of buying and selling corn in Malala Village is not in accordance with the true teachings of Islam. Even though there is a mutualism symbiosis here, there are still parties who feel disadvantaged. The pattern of buying and selling yellow maize in Malala Village is not in accordance with several principles of sharia economic law. Because the conditions in the cooperation agreement contract are not fulfilled and have the principle of honesty and state their claim to the principles of a taradin minkum and la tazhlimuna wa la tuzhlamun on the aspects of buying and selling patterns between farmers and collectors.
\end{abstract}

Keywords: Collectors; Farmer; Islamic Law; Selling and Buying.

\begin{abstract}
Abstrak
Desa Malala merupakan daerah di kecamatan Dondo kabupaten Tolitoli yang sebagian masyarakatnya mendapat penghasilan dari bercocok tanam. Salah satunya yaitu Jagung Kuning. Hasil dari aktivitas bercocok tanam jagung kuning kemudian diperdagangkan melalui pedagang pengepul. Dalam sistem perdagangan jagung kuning ini terjadi perbedaan posisi tawar pada tiap petani, yaitu petani yang mendapat bantuan modal bibit dari pengepul mendapat posisi tawar lebih rendah, sebagai gantinya mereka mendapatkan sembako dari pengepul sesuai kesepakatan diawal perjanjian sedangkan petani tanpa bantuan bibit dari pengepul mendapat posisi tawar yang normal. Petani yang mendapatkan posisi tawar rendah merasa rugi, namun tetap melakukan karena tidak memiliki modal bibit. Sistem jual beli seperti ini telah menjadi kebiasaan masyarakat setempat. Pola jual beli jagung kuning di Desa Malala menurut peneliti belum sesuai dengan ajaran Islam yang sebenarnya. Meskipun terdapat symbiosis mutualisme disini namun masih ada pihak yang merasa dirugikan. Pola dari jual beli jagung kuning di Desa Malala belum sesuai dengan beberapa prinsip hukum ekonomi syariah. Karena tidak terlaksananya syarat dalam akad perjanjian kerjasama serta terdapat pelanggaran prinsip kejujuran dan mengindikasikan adanya pelanggaran terhadap prinsip an taradin minkum dan la tazhlimuna wa la tuzhlamun pada aspek pola jual beli antara petani dan pengepul.
\end{abstract}

Kata kunci: Hukum Islam; Jual beli; Petani; Pengepul.

TADAYUN:

Jurnal Hukum Ekonomi Syariah

Vol.1 No.2, Juli-Desember 2020 | 139

E-ISSN: 2774-4914 


\section{A. PENDAHULUAN}

Setiap manusia berhak untuk memenuhi kebutuhan hidupnya di dunia ini, antara lain kebutuhan akan sandang dan pangan, untuk memenuhi semua itu tentunya harus ada usaha untuk mengelolah lahan tanah yang mereka miliki, antara lain dengan bercocok tanam dan lain sebagainya, yang menjadi persoalan saat ini adalah, ketika seseorang tidak memiliki modal untuk mengelolah lahan mereka, maka akan dibutuhkan orang lain dalam hal ini yakni orang yang mempunyai modal untuk melakukan kerjasama.

Di Desa Malala Kecamatan Dondo Kabupaten Tolitoli yang mana orang yang mempunyai lahan namun tak mempunyai modal untuk mengelolah lahannya, Dalam pertanian jagung kuning di Desa Malala, pedagang pengumpul (pengepul) dan petani bekerjasama, yaitu pengepul memberikan bibit secara gratis kepada petani, kemudian pengepul memberikan kemudahan dengan memboleh kepada petani untuk mengambil kebutuhan mereka sebelum datang waktu panen, namun pengambilan petani tersebut akan dipotong setelah penjualan hasil panen. Dan hasil pertanian jagung tersebut harus dijual kepada pengepul. Selain petani yang menerima modal dari pengepul, adapula petani yang melakukan transaksi dengan pengepul tanpa menerima bantuan modal bibit. Kendala dalam pemasaran oleh petani dalam bentuk jagung kuning, dimana petani selalu berada pada posisi tawar yang rendah karena harga sering kali ditentukan oleh pengepul.

Dari informasi yang didapatkan bahwa bila harga normal berkisar 3000 perkilogram maka pengepul membeli dengan harga 2200 kepada yang petani telah diberikan bibit secara gratis oleh pengepul. Nah ini yang menjadi permasalahan bagi petani jagung kuning, walaupun mereka telah diberikan kebolehan untuk mengambil kebutuhan hidup namun mereka merasa dirugikan dengan sistem jual beli tersebut, dikarenakan harga yang mereka dapatkan terlalu murah atau berbeda jauh dengan harga normal seperti yang didapatkan oleh petani yang mempunyai modal, namun karena tuntutan hidup maka mereka tetap melakukan jual beli dengan pengepul.

Jual beli dengan sistem ini kerap dikerjakan oleh warga pedesaan khususnya di Desa Malala kecamatan Dondo Kabupaten Tolitoli, disebabkan kurangnya modal petani untuk melakukan penanaman jagung kuning serta untuk mencukupi kebutuhan hidup. 
Yang menjadikan penelitian ini menarik adalah untuk mengetahui seperti apa pola jual beli jagung kuning antara petani dan pengepul yang telah menjadi kebiasaan di daerah ini jika ditinjau dari hukum Ekonomi Islam.

\section{B. METODE PENELITIAN}

Metode yang digunakan pada penelitian ini adalah jenis penelitian lapangan yang mana penulis menggali pola perdagangan jagung kuning di desa malala kecamatan Dondo Kabupaten Tolitoli dengan pendekatan deskriptif-kualitatif. Adapun pengecekan keabsahan digunakan tekhnik Triangulasi sumber, teknik, dan waktu ${ }^{1}$ yang mana untuk keabsahan peneliti mengecek data yang diperoleh dari petani yang satu dengan petani yang lainnya. Kemudian setelah mendapatkan hasil wawancara kemudian dicek dengan hasil observasi dan dukumen, sehingga penyajian informasi yang di peroleh dalam hasil penelitian ini lebih jelas dan akurat. Serta waktu observasi dan wawancara dalam waktu yang berbeda dilakukan misalnya pagi, siang, sore dan malam. Kemudian hasil deskripsi dari pola perdagangan dianalisis dengan menggunakan tinjauan hukum ekonomi Islam.

\section{HASIL DAN PEMBAHASAN}

\section{Masyarakat Desa Malala Kecamatan Dondo Kabupaten Tolitoli}

Desa Malala memiliki 3 Dusun dengan jumlah penduduk mencapai 3,026 jiwa, laki-laki berjumlah 1522 jiwa dan jumlah penduduk perempuan berjumlah 1,504 jiwa. Mayoritas Usia masyarakat yang bermukim di Desa Malala 22.54\% berusia 31-45 Tahun dan 20.39\% berusia 20-30 Tahun. Adapun bidang kehidupan masyarakat Desa Malala :

a. Pendidikan

Masyarakat di Desa Malala pada umumnya memiliki semangat yang tinggi untuk menempuh pendidikan dalam sekolah. Semangat yang tinggi tersebut diperhadapkan pada berbagai kendala terutama masalah ekonomi keluarga yang relative kurang mencukupi untuk membiayai kelanjutan sekolah anggota keluarga. Sehingga terdapat

${ }^{1}$ Nusa putra dan Santi Lisnawati, Penelitian Kualitatif Pendidikan Agama Islam (Cet. II; Bandung: PT Remaja Rosdakarya, 2013), 34. 
anak yang usia sekolah namun tidak bersekolah. Namun kenyataan lainnya, meskipun tidak banyak tapia ada juga masyarakat yang dapat menyekolahkan anak-anaknya pada sekolah/lembaga pendidikan pada sekolah dasar (SD) dan sekolah lanjutan tingkat pertama (SLTA) dan Diploma bahkan hingga Sarjana.

b. Agama

Agama yang dianut atau diyakini oleh penduduk Desa Malala adalah Agama Islam, Kristen Protestan, Kristen Katolik, Hindu. Keempat jenis agama yang dianut tersebut yang paling banyak penganutnya adalah Agama Islam yakni berjumlah 2,971 orang atau 98,18 persen. Hal ini menjelaskan bahwa mayoritas masyarakat daerah ini memeluk Agama Islam.

c. Ekonomi

Penduduk Desa sesuai hasil pendataan menunjukkan bahwa mata pencaharian yang banyak digeluti oleh Masyarakat di Desa Malala adalah petani. Apabila diprosentasekan menunjukkan bahwa penduduk yang menekuni mata pencaharian petani menempati angka terbesar yaitu 740 orang atau 34,16 persen dari seluruh penduduk produktif, sedangkan angka terbesar kedua yaitu buruh tani yakni berjumlah 480 orang atau 22,16 persen.

\section{Pola Jual Beli Jagung Kuning Di Desa Malala Kecamatan Dondo}

Setelah melihat jumlah penduduk menurut mata pencaharian, maka dapat disimpulkan bahwa mayoritas penduduk Desa Malala adalah petani. Desa Malala merupakan salah satu Desa yang berpotensi dibidang pertanian dan perkebunan. Kondisi lahan yang tersedia memberikan harapan bagi masyarakat dalam membuka nuansa perekonomian di desa ini. Menurut Ibu Mariati selaku PPL di Desa Malala, dan beberapa informan lainnya.

Lahan yang tersedia di Desa Malala ini sangat baik digunakan sebagai lahan pertanian dan perkebunan. Hal ini terbukti dengan banyaknya tanaman padi sawah, coklat, kelapa, nilam, pala, dan beberapa tanaman bulanan lainnya seperti kacang tanah, jagung, sayur mayur yang tumbuh subur di Desa Malala. Tanaman jagung juga banyak dipertanikan karena hasilnya bagus dan tahan dimusim panas dan hujan ${ }^{2}$

${ }^{2}$ Mariati, PPL “Wawancara” Rumah Warga, Tanggal 08 Agustus 2019 
Dari penjelasan wawancara di atas, dapat dipahami bahwa, lahan pertanian dan perkebunan yang ada di Desa Malala ini sangat baik dan berpotensi untuk dijadikan sebagai lahan untuk bercocok tanam. Dan jagung kuning merupakan salah satu tanaman yang dominan dipertanikan di Desa Malala karena hasilnya bagus.

Sistem jual beli jagung kuning di Desa Malala adalah diawali dari kerjasama antara petani dan pedagang pengumpul (pengepul), yang mana pengepul yang memberikan bibit kepada petani kemudian hasil dari pertanian jagung kuning tersebut harus dijual kepada pembeli tersebut. Dan dari kesepakatan tersebut petani dapat mengambil sembako kepada pengepul yakni orang yang memberikan bibit kepada petani. Contohnya mengambil beras, gula dan petani juga boleh mengambil racun dan pupuk dengan kesepakatan pengambilan tersebut dipotong pada saat penjualan jagung kuning oleh petani dan disesuaikan dengan perkiraan hasil panen. Menurut Bapak Ahmad selaku petani.

Saya menanam jagung sudah 2 tahunan, bibit saya dapat dari pengepul dengan kesepakatan hasilnya harus dijual kepada pengepul. Yang membuat saya mau karena pengepul membolehkan saya mengambil kebutuhan seperti uang, beras, pupuk dan racun sebelum panen. Karena memang kehidupan petani seperti saya kebutuhan hidup kadang tidak mencukupi ${ }^{3}$

Namun dalam jual beli jagung kuning di Desa Malala ada pula yang melakukan jual beli jagung kuning dengan normal, yaitu petani yang mempunyai bibit jagung sendiri, tidak melakukan pengambilan kepada pengepul dan harga yang mereka dapatkan adalah harga normal yaitu 3000 perkilonya. Salah satu petani, Bapak Uki menjelaskan yaitu.

Saya bertani jagung kuning bibitnya saya beli sendiri, dan saya tidak bergantung pada pengepul, jadi saya kalau mau jual terserah saya mau jual dimana. Dan harga yang saya dapat sesuai dengan harga pasaran 3000 perkilo. ${ }^{4}$

Dari wawancara tersebut dapat disimpulkan bahwa petani yang pertama bertani jagung karena bibit mudah didapat. Dan petani juga tertarik karena dimudahkan bisa mengambil kebutuhan hidup kepada pengepul, dikarenakan tuntutan kehidupan.

${ }^{3}$ Ahmad Petani Jagung Kuning, “Wawancara”, Tanggal 07 Agustus 2019

${ }^{4}$ Uki Petani Jagung Kuning, “Wawancara”, Tanggal 09 Agustus 2019 
pengambilan tersebut disesuaikan dengan perkiraan hasil panen dan pengambilan petani tersebut akan dipotong setelah penjualan.

Salah satu kesepakatan yang pengepul dan petani lakukan adalah masalah harga, agar tidak terjadi kesalahpahaman di akhir atau setelah jagung kuning tersebut dijual. Harga yang diberikan pengepul kepada petani yang dia modali adalah 2,200 karena menurut pengepul dihitung dari biaya bibit, dan telah menolong petani boleh mengambil kebutuhan kepadanya, dan untuk lebih jelasnya dilihat dari hasil wawancara kepada bapak Yayan, kurang lebih sebagai berikut:

Harga yang saya kasih kepada petani jagung kuning 2,200, karena bibit saya kasih gratis. kemudian jagung tersebut akan saya jual kembali ke Kota Tolitoli, maka akan membutuhkan biaya lagi kemudian petani juga sudah saya bantu, boleh ambil kebutuhan sama saya sebelum panen, tapi saya perkirakan dengan hasil pertanian jagung mereka. itu yang saya perhitungkan. ${ }^{5}$

Menurut penulis harga jagung yang pengepul kasih kepada petani yang ia beri bibit terlalu murah yaitu 2200, hanya karena ia memberi bibit kepada petani dan membolehkan mengambil uang dan sembako sebelum panen. Di Desa Malala juga ada beberapa pembeli jagung kuning dengan harga normal 3000 (tidak member bibit dan tidak memberi sembako sebelum panen). Nah disini dapat dilihat perbedaan harga jagung kuning diantara pengepul yaitu 800 rupiah.

\section{Tinjauan Hukum Ekonomi Islam Terhadap Pola Jual Beli Jagung Kuning di Desa Malala Kecamatan Dondo Kabupaten Tolitoli}

Islam sangat mementingkan masalah Muamalah, termasuk mengatur masalahmasalah ekonomi, sehingga manusia mampu untuk memenuhi kebutuhan hidupnya, pada dasarnya manusia berharap memeperoleh kehidupan lebih baik, Bukan sekedar hanya kehidupan di dunia, tapi di akhirat nantinya. Sehingga dibutuhkan pengupayaan unsur materi yang bertujuan bagi kesejahteraan dunia dan akhirat (falah). Islam mengajarkan agar manusia menjalani kehidupannya secara benar, sebagaimana yang telah diatur oleh Allah, bahkan usaha untuk hidup secara benar dan menjalani hidup secara benar inilah yang menjadikan kehidupan seseorang menjadi bernilai. Islam adalah sistem kehidupan, dimana Islam telah menyediakan berbagai perangkat aturan

${ }^{5}$ Yayan, Pengepul. “Wawancara” Tanggal 07 Agustus 2019 
yang lengkap bagi kehidupan manusia, termasuk dalam bidang ekonomi. ${ }^{6}$ Ekonomi Islam dibangun atas dasar agama Islam, karenanya ia tak terpisahkan dari agama Islam. Ekonomi Islam akan mengikuti agama Islam dalam berbagai aspeknya,

Dalam hukum ekonomi Islam ada beberapa prinsip yang dianggap penting dan menjadi sorotan dalam melakukan kegiatan perekonomian antara lain. pada 1). Pelaksanaan perjanjian, 2). Prinsip Tolong menolong, 3). Prinsip Kejujuran. 4). Prinsip Keadilan, 5). Prinsip Amanah.

a. Perjanjian/akad

Dalam melakukan kegiatan muamalah, perjanjian merupakan hal yang penting dalam melakukan kegiatan muamalah, sehingga Islam menganjurkan untuk melakukan atau membuat adanya bukti secara tertulis setiap melakukan kerjasama atau perjanjian, sehingga apabila ada masalah di kemudian hari, bisa dipertanggung jawabkan.

Dalam hasil penelitian, sistem jual beli jagung kuning di Desa Malala, dalam melakukan kesepakatan jual beli, tidak ada bukti secara tertulis yang mereka buat, melainkan hanya berupa ucapan lisan semata, dan sikap saling percaya diantara mereka. Sehingga ketika ada masalah akan sulit untuk dipertanggungjawabkan. Seperti yang diungkapkan oleh bapak Rusdin antara lain sebagai berikut:

Sebelum bibit jagung kuning diberikan kepada saya, ada kesepakatan yang kami lakukan yaitu, bibit diberikan kepada saya secara cuma-cuma, saya juga boleh mengambil kebutuhan saya kepadanya, namun dipotong setelah panen. dengan syarat hasilnya harus dijual kepada pemberi bibit tadi. Dalam kesepakatan atau perjanjian ini kami hanya saling percaya, tidak secara tertulis. ${ }^{7}$

Perjanjian jual beli di Desa Malala, tidak melakukan pencatatan secara tertulis, adanya rasa saling percaya, cukup meyakinkan bahwa kerja sama yang mereka buat ini akan berlangsung dengan baik, dan kebiasaan seperti ini sudah lama dilakukan oleh orang-orang. Sudut pandang penulis, perjanjian yang baik seharusnya dilakukan secara tertulis agar posisinya dalam hukum kuat karena memiliki bukti. Menghindari akan adanya wanprestasi atau pelanggaran dalam kontrak lainnya yang mungkin saja terjadi

${ }^{6}$ Pusat Pengkajian dan Pengembangan Ekonomi Islam, Ekonomi Islam, (Cet. VII; Rajawali Pers,2015), 13.

${ }^{7}$ Rusdi, petani jagung kuning, Wawancara Tanggal 10 Agustus 2019. 
nantinya sehingga kerugian yang terjadi dapat diproses melalui hukum. Namun jika perjanjian yang dilakukan tidak tertulis melainkan hanya melalui lisan, akan sulit jika terjadi masalah kedepannya karena tidak memiliki bukti konkret terkait perjanjian yang telah diikat.

Jika akad seperti ini dikategorikan dalam akad kerjsama maka terdapat ketidakjelasan besaran modal dan hasil panen serta proporsi pembagian modal yang menjadi syarat dalam akad kerjasama tidak terlaksana yang berakibat tidak sahnya suatu akad kerjasama jika ditinjau melalui hukum Islam. Jika akadnya menggunakan akad jual beli, maka 800 rupiah yang dipotong dari harga jagung kuning sebagai harga beli bibit, sembako dan keperluan petani yang diambil dari pengepul. Tentu saja ini juga ketidakjelasan/ gharar dalam barang yang diterima dan harga, serta terdapat ketidakpastian (uncertainty) besaran panen yang dihasilkan. Praktik ini terjadi pada jual beli jagung kuning dengan pola kerjasama antara petani dan pengepul karena kurangnya literasi kepada petani terkait dengan hal-hal yang berkaitan dengan perjanjian serta kebutuhan modal petani yang memaksa mereka harus menyetujui perjanjian tersebut.

b. Tolong Menolong

Sistem jual beli yang dilakukan di Desa Malala ini, mempunyai dampak yang positif dan negatif diantara mereka. Bapak Sarman selaku petani, mengutarakan:

Saya menanam jagung kuning sudah lumayan lama, sekitar 3 tahun. Kesepakatannya saya dikasih bibit, dan saya boleh ambil kebutuhan hidup kepada pemberi bibit. Disitu saya merasa teringankan karena itu saya masih mau bertani jagung sampai sekarang. Disisi lain saya juga merasa dirugikan sebab harga yang dia kasih 2200 normalnya 3000, dan biasanya saya dapat 1 sampai 2 ton, jadi kalau 1 ton seharusnya saya dapat 3.000.000 namun yang saya dapat hanya 2.200.000 harganya berbeda jauh dengan harga normalnya. Dan yang saya dapat dari hasil penjualan jagung tersebut kadang sudah tidak ada, karena habis terpotong dari pengambilan kebutuhan keluarga saya. ${ }^{8}$

Dilihat dari wawancara diatas bahwa petani merasa terbantu karena telah dimudahkan yaitu diberikan modal bibit dan dibolehkan mengambil kebutuhan hidup. Namun dilihat dari segi lain petani merasa dirugikan karena harga yang diberikan kepada mereka berbeda dengan harga normal. Dan menurut penulis transaksi yang

${ }^{8}$ Sarman, Petani Jagung Kuning “Wawancara" Tanggal 6 Agustus 2019 
dilakukan petani dan pengepul tidak murni tolong menolong karena ada keinginan menghasilkan keuntungan besar yang diharapkan oleh pengepul dengan memberikan bantuan modal kepada petani.

Tujuan Ekonomi Islam ialah untuk mencapai kemaslahatan dan ridha dari Allah SWT dan juga sangat memperhatikan adanya sikap saling tolong-menolong dalam melakukan kegiatan ekonomi. Allah berfirman dalam Q.S. Al-Maidah (5): 2. Dengan Terjemahnya:

"Dan tolong-menolonglah kamu dalam (mengerjakan) kebajikan dan takwa, dan jangan tolong-menolong dalam berbuat dosa dan pelanggaran. dan bertakwalah kamu kepada Allah, Sesungguhnya Allah Amat berat siksa-Nya." Q.S. Al-Maidah (5): 2. ${ }^{9}$

Allah Ta'ala memerintahkan hambanya yang beriman untuk senantiasa tolongmenolong dalam berbuat kebaikan apa yang diperintahkan kepada kalian dan meninggalkan apa yang terlarang bagi kalian. Meninggalkan segala bentuk kemunkaran dan Allah melarang untuk saling membantu dalam berbuat dosa dan mengerjakan sesuatu yang haram. Ibu Jarir berkata dosa yang dimaksudkan dalam ayat tersebut berarti meninggalkan apa yang oleh Allah perintahkan untuk mengerjakannya, sedangkan pelanggaran, berarti melanggar apa yang telah ditetapkan Allah dalam urusan agama dan melanggar apa yang telah diwajibkan-Nya. ${ }^{10}$

c. Kejujuran

Pada dasarnya Islam membolehkan semua bentuk jual beli, selama jual beli tersebut tidak bertentangan dengan syar'i dan saling menguntungkan dan mendatangkan maslahat yang baik terhadap dirinya dan masyarakat banyak, berbeda halnya dengan sistem jual beli jagung kuning di Desa Malala, Pelaksanaan jual beli, berlangsung dengan sistem kepercayaan yang tidak kuat membuat jual beli ini berlangsung dengan kurang baik.

Setelah datang waktu panen sebelum datang pengepul, biasanya ada beberapa orang membeli jagung kepada saya, biasanya 3 sampai 5 orang untuk pakan ayam mereka, ada yang membeli 5 sampai $10 \mathrm{~kg}$. Saya menjual kepada mereka 2010), 209.

${ }^{9}$ Kementrian Agama Republik Indonesia, Al-Qur'an dan Terjemahan (Bandung: Syamil Quran,

${ }^{10}$ Abdullah Muhammad, Tafsir Ibnu Katsir Jilid 3, Terj. M. Abdul Ghofar, (Bogor: Pustaka Imam asy-Syafi'I, 2003), 9 
secara ecer dengan harga 2800 perkilo. Dari pada semuanya dijual kepada pengepul harganya Cuma 2,200 maka saya jual sebagian kepada mereka. ${ }^{11}$

Dari hasil wawancara di atas dapat disimpulkan bahwa, sifat jujur belum diterapkan dalam sistem jual beli jagung kuning di Desa Malala. Terutama kepada petani jagung kuning, yaitu melanggar kesepakatan bahwa jagung kuning tersebut hanya akan dijual kepada pengepul.

Jujur berarti adanya konsistensi antara kepercayaan, sikap, ungkapan dan perilaku. Kejujuran merupakan aspek penting dan prasyarat dalam keadilan. Kejujuran merupakan tuntutan yang mutlak untuk bisa mencapai kebenaran dan keadilan. Bila seseorang tak bisa berlaku jujur dalam suatu hal maka keputusan yang diambil dalam urusan itu dipastikan tidak benar. ${ }^{12}$ Allah berfirman dalam Q.S Al-Ahzab ayat ke-70, dengan terjemahnya: "Hai orang-orang yang beriman, bertakwalah kamu kepada Allah dan katakanlah perkataan yang benar."

Bertakwalah kamu sekalian kepada Allah dan katakanlah perkataan yang benar, yakni perkataan yang lurus, tidak bengkok dan tidak menyimpang. ${ }^{13}$ Ayat di atas memerintahkan kepada orang-orang yang beriman agar bertaqwa kepada Allah, menjalankan segala perintahnya dan menjauhi segala larangannya, kemudian Allah memerintahkan agar mengatakan perkataan yang benar.

d. Keadilan

Kemudian dalam aspek keadilan pada pola jual beli jagung kuning di Desa Malala dapat dicermati pada hasil wawancara kepada bapak Burhan selaku petani.

Saya merasa dirugikan oleh pengepul, karena perbedaan harga 2,200. Yang saya dapat padahal harga petani lain yang tidak diberi bibit harga yang mereka dapat $3000 .^{14}$

Berdasarkan wawancara diatas dapat kita simpulkan bahwa salah satu petani merasa dirugikan karena harga yang jauh berbeda. Tapi jika bersikap objektif keadilan itu bersifat relatif dan berbeda tidak bisa dilihat hanya dari sekedar adanya perbedaan.

${ }^{11}$ Masnia, Petani Jagung Kuning “Wawancara” Tanggal 7 Agustus 2019

${ }^{13}$ Muhammad, Abdullah, Tafsir Ibnu Katsir Jilid 6, Terj. M. Abdul Ghofar, (Bogor: Pustaka Imam asy-Syafi'I, 2003), 542

${ }^{14}$ Burhan, Petani Jagung Kuning. “wawancara”, tanggal 08 Agustus 2019. 
Keadilan pada dasarnya menempatkan sesuatu pada tempat yang semestinya. Karena perbedaan dalam posisi tawar rendah didapatkan karena petani tidak mengeluarkan modal untuk bibit, serta mendapatkan sembako dan kebutuhan dari penyedia/pengepul sehingga jika diperhitungkan maka seharusnya tidak terdapat adanya pihak yang merasa tidak adil. serta jika menggunakan konsep adil dalam Islam, seharusnya tidak ada yang menzalimi dan terzalimi. ${ }^{15}$

Allah berfirman dalam surah An-Nahl ayat ke-90 dengan terjemahnya "Sesungguhnya Allah menyuruh (kamu) berlaku adil dan berbuat kebajikan". ${ }^{16}$

Ayat tersebut memerintahkan kepada kita untuk berlaku adil dalam hal ini adil dalam kegiatan muamalah, serta bersikap benar, berbuat kebajikan atau menegakkan kebenaran. Ketidakadilah yang dirasakan oleh salah satu pihak sebenarnya karena kurangnya literasi diawal saat mengikat perjanjian untuk menerima modal bibit. Hal ini yang seharusnya di perbaiki untuk menghindari timbulnya transaksi yang melanggar prinsip an taradin minkum dan la tazhlimuna wa la tuzhlamun.

e. Amanah

Amanah merupakan tujuan hidup seorang muslim. Kepribadian amanah dalam diri seseorang akan menghadirkan sikap kreadibilitas dan sifat bertanggung jawab yang tinggi pada diri kaum muslim. Sekumpulan orang-orang yang memiliki karakteristik kreadibilitas serta tanggungjawab akan menghadirkan komunitas yang kuat, karena dilandasi dengan saling percaya antar anggotanya. Pemberian amanah dan pelaksanaannya harus berjalan secara seimbang. Melakukan transaksi bermodalkan kepercayaan seperti yang diterapkan pada daerah ini, maka benar-benar harus memegang amanah. Pada aspek ini belum terdapat penyimpangan amanah antara salah satu pihak yang mana terlihat bahwa petani menjual hasil perkebunannya tanpa sepengetahuan dari pengepul sesuai dengan perjanjian diawal dengan persyaratan seluruh hasil panen dijual kepada pengepul bukan kepada orang lain.

Amanah dalam bermuamalah menjadi sesuatu yang penting. Rasulullah mengisyaratkan hal tersebut dalam hadis yang diriwayatkan oleh Abu Dawud, dengan

\footnotetext{
${ }^{15}$ Arfin Hamid, Hukum Ekonomi Islam (Ekonomi Syariah) di Indonesia Aplikasi dan Prospektifnya, (Bogor: Ghalia Indonesia, 2007), 120-121

${ }^{16}$ Enang Hidayat. Fiqih Jual Beli. (Bandung: PT Remaja Rosdakarya 2015)
} 
terjemahnya "Aku adalah pihak ketiga dari dua orang yang bersekutu selama salah seorang dari mereka tidak menghianati kepercayaan patnernya, aku akan keluar dari persekutuan apabila ada yang menghianatinya" maksud perkataan Rasulullah adalah Allah akan selalu menyertai sebagai penolong dalam sebuah bisnis jika dijalankan dengan amanah, namun jika ada yang melakukan khianat maka bisnis tersebut akan jauh dari keberkahan. ${ }^{17}$

\section{KESIMPULAN}

Pelaksanaan sistem jual beli jagung di Desa Malala diawali dari pemberian bibit secara gratis oleh pedagang pengumpul (pengepul) kepada petani, kesepakatannya hasil panen jagung tersebut harus dijual kepada pengepul. Dalam kesepakatan tersebut juga memberikan dampak positif bagi petani karena mereka boleh mengambil uang, sembako atau kebutuhan lainnya dilihat dari perkiraan hasil panen. Hasil panen jagung di jual kepada pengepul dengan tawaran yang rendah karena dianggap sebagai potongan atas pembiayaan modal yang diberikan oleh pengepul.

Pola dari jual beli jagung kuning di Desa Malala belum sesuai dengan beberapa prinsip hukum ekonomi syariah. Karena tidak terlaksananya syarat dalam akad perjanjian kerjasama serta terdapat pelanggaran prinsip kejujuran dan mengindikasikan adanya pelanggaran terhadap prinsip an taradin minkum dan la tazhlimuna wa la tuzhlamun pada aspek pola jual beli antara petani dan pengepul.

\section{REFERENSI}

Hamid. Arfin, Hukum Ekonomi Islam (Ekonomi Syariah) di Indonesia Aplikasi dan Prospektifnya, Bogor: Ghalia Indonesia, 2007

Hidayat. Enang, Fiqih Jual Beli, Bandung: PT Remaja Rosdakarya, 2015

Kementrian Agama Republik Indonesia, Al-Qur'an dan Terjemahan, Bandung: Syamil Quran, 2010

Mardhani, Fiqh Ekonomi Syariah: Fiqh Muamalah, Jakarta: Kencana, 2012

Mursal dan Suhadi, Implementasi Prinsip Islam dalam Aktivitas Ekonomi: Alternatif Mewujudkan Keseimbangan Hidup, Jurnal Penelitian, Vol 9 No 1, Februari 2015

\footnotetext{
${ }^{17}$ Mursal dan Suhadi, Implementasi Prinsip Islam dalam Aktivitas Ekonomi: Alternatif Mewujudkan Keseimbangan Hidup, Jurnal Penelitian, Vol 9 No 1, Februari 2015, 73-75
} 
Muhammad. Abdullah, Tafsir Ibnu Katsir Jilid 1-8, Terj. M. Abdul Ghofar, Bogor: Pustaka Imam asy-Syafi'I, 2003

Putra. Nusa dan Santi Lisnawati, Penelitian Kualitatif Pendidikan Agama Islam, Cet. II, Bandung: PT Remaja Rosdakarya, 2013

Pusat Pengkajian dan Pengembangan Ekonomi Islam, Ekonomi Islam, Cet. VII, Rajawali Pers, 2015 
